\title{
Haunted Knights in Spandex: Self and Othering in the Superhero Mythos*
}

\author{
Elastik Hayalet Şövalye: Süper Kahraman Söylencesinde Kendilik ve Ötekilik
}

\section{Pramod K. NAYAR ${ }^{* *}$}

\begin{abstract}
This essay looks at the dynamics of self and the Other in superhero comics. The self-other dynamic in superhero mythos is an instance of the uncanny, which includes themes of doubling, ghostliness and a haunting that is the tension between the familiar and the unfamiliar, or the unfamiliar that partakes of the familiar. Superheroes are instances where the uncanny asserts itself between the self-other dichotomy. Second, I suggest, filiation (to do with the family and therefore the "home") folds into affiliation, where affiliations build on, substitute for and supplant the familial. Third, the self of the superhero lies not in a sense of the self but in selflessness. I argue that it is the altruistic self that separates the superhero from the Other, the passive, spectator human. Fourth, I propose that superheroes present a certain utopian promise. I align the superhero with the posthuman (the technologically advanced humans of cybercultures), as signifying human perfectibility.
\end{abstract}

Keywords: Superheroes, comics, uncanny, transhumanism

Özet: Bu makalede süper kahraman çizgi romanlarında kendi ve öteki kavramlarının ilişkisini çalışmaktadır. Süper kahraman söylencesindeki kendi ve öteki ilişkisi özellikle esrarengiz olanın bir görünümüdür ve bu görünüm çoğaltma, hayalet basması gibi bilindik ve bilinmedik arasındaki tansiyonun sonucudur. Çoğu kez, bu durum bilinmedik olanın bilinenin yerini almasıyla görünür. Süper kahramanlar esrarengiz olanın kendi ve öteki arasındaki zıtlıkta yer edinir. İkinci olarak, aile ve yuvayla ilgili olanın ait olmamaya döndüğünü ve ait olmama durumunun da aile ve yuvayla ilgili olanın yerini aldığını iddia ediyorum. Üçüncü olarak, süper kahramanın kendiliği aslında kendiliğinde değil kendisizliğinde yatmaktadır ki, düşüncem süper kahramanı edilgen ve izleyici olan ötekinden ayıran şey onun özgeciliğidir. Dördüncü olarak da önerim süper kahramanın belirli bir ütopik söz vermişlik sahibi olduğudur ki; bu da onun insan-sonrası denilebilecek siber-kültürel bir aşkın insan olması ve bu yönüyle insan mükemmelliğini temsil ettiğidir.

Anahtar sözcükler: Süper kahraman, çizgi roman, esrarengiz, trans-insanlık

The self-other dichotomy is complicated in very different ways in the superhero universe. All superheroes, it is assumed for the purposes of this essay, are manifestations of cultural anxieties and desires. When we read superhero books or watch their films we understand the problems of evidence, of justice and of legal processes. They help us understand the limitations of the law in altering the nature of justice. The law acquires both cultural legibility and cultural legitimacy when public narratives generate a particular popular perception of it. If "cultural legibility" is the narratological -representational- foundation of abstract notions of justice which partake of social systems of signification, and share a vocabulary and grammar of violations, claims, rights and intervention, "cultural legitimacy" is the popular acceptance of the norms, values and belief

\footnotetext{
* An earlier draft of this essay was presented at a conference on 'Self and the Other', Department of Humanities and Social Sciences, Indian Institute of Technology, Mumbai, India February 2011

** Department of English, University of Hyderabad, India, pramodknayar@gmail.com
} 
systems through the consumption of these narratives when the society embeds the norms in their own contexts. Popular perceptions of the law -whether of its majesty, corruption, inefficiency or inadequacy- enable the definition of the law itself. Writing about such popular perceptions of law realized through such cinematic representations - even fictional ones, Chase comments that popular perceptions [of the law] are constituent elements in the social process by which any legal culture becomes recognizable to its own participants (Chase, 2000, 559-560).

Popular culture is, in other words, the discursive terrain on which larger social issues are played out, often unobtrusively and masked as entertainment - and this is precisely why pop culture needs to be examined even more closely than clearly polemical or propagandist tracts.

That the superhero's self is schizophrenic with the secret identity masked, literally, by the neerdy, helpless and passive one is a truism I do not wish to rehearse here. Second, the superhero mythos has been subject to revisionism, especially from the 1980s (a starting date would be 1986 when Frank Miller published his Batman: The Dark Knight Returns -the first work in the superhero comics genre that synthesizes 45 years of Batman history in one story arc- and Alan Moore published Watchmen). In the revisionist narrative the core myths of superheroism are called into question and the distinction between good and bad guys gets blurred, origin stories are redone and we are forced to examine the thematic of violence and sexuality (when, for instance, Miller portrays Batman and the girl Robin in a clinch in TDKR; see also Klock, 2002). Thus the identity of the superhero has itself undergone changes, even as new, problematic superheroes who do not fit the traditional pattern have emerged in texts like Marvels and the Kingdom Come series. Henry Jenkins therefore argues a case for treating the genre as presenting multiplicity rather than continuity where readers "consume multiple versions of the same franchise, each with different conceptions of the character, different understandings of their relationships with secondary figures, different moral perspectives, exploring different moments in their lives" (Jenkins, 2009, 20-21).

I want to move beyond the traditional reading of the superhero's secret identity into another set of 'problems'. First, this essay makes a case for reading the self-other dynamic in superhero mythos as an instance of the uncanny. The uncanny first famously theorized by Freud and later elaborated in interesting ways by a wide variety of commentators (whose interest in spandex is, however, not known) such as Tzvetan Todorov, Samuel Weber, Hèléne Cixous, Nicholas Royle and others, is about doubling, ghostliness and a haunting that is the tension between familiarity and the unfamiliar, or the unfamiliar that partakes of the familiar. Superheroes like Batman, I argue, are instances where the uncanny asserts itself between the self-other dichotomy. Second, one of the loci of the self-in-the-world, is relationships. In the superhero mythos, I suggest, filiation (to do with the family and therefore the "home" and the immediate relationships where the self is nurtured and socialized) folds into affiliation. Affiliations build on, substitute for and supplant the familial here and a new form of kinship and family, based on ideology and mutual support characterizes the superhero. Third, the self of the superhero lies not in a sense of the self but in selflessness. Embodying what superhero storywriters Jeph Loeb and Tom Morris have called "altruistic activism", the superhero finds a self in a work ethic ("it is not what I am underneath, but what I do that defines me”, as Batman, rather pompously, pronounces in Christopher Nolan's 2005 film Batman Begins). I argue that it is the altruistic self that separates the superhero from the Other, the passive, spectator human. Fourth, I want to propose that superheroes present a certain utopian promise. They do not constitute an Other to the ordinary human but rather function as embodiments of a cultural desire for perfection. Here I align the superhero with the posthuman (the technologically advanced humans of cybercultures), as signifying human perfectibility. Thus the superhero is synecdochic of a utopian goal -faster, higher, better- of what we can become. $\mathrm{S} /$ he represents an evolving Self, a becoming rather than Being. 


\section{Haunting, the Uncanny and the Question of the Self}

Frank Miller's Batman: Year One opens with an image of a Bruce Wayne whose body is partially obscured -we see his grimacing face, his legs and one palm, the chair on which he sits seems to be dripping- by the huge shadow cast by a batwing. The accompanying text reads: "he will become the greatest crimefighter the world has ever known ... it won't be easy". The superimposition of the batwing on the ordinary-clad Bruce Wayne symbolizes the entire Batman mythos: of haunting. This mythos is complicated by a troubled masculinity in Miller's re-creation of one of the greatest superheroes in the comicbook universe.

The question of the self in superhero cultures is not simply one of a sense of self-hood rooted in a name, a family, a location and a clear vision of what the "I" is. Rather, the self in superheroes is one of haunting. One of my informing assumptions here is that comicbook universes, especially superhero ones, embody a wholly different order of self-hood. I am not, in this paper, examining either the racial or gendered dimensions of the superhero comic genre, topics on which substantial criticism has been produced already (See also Robinson, 2004; and more recently Stabile, 2009).

Examining representations of masculinity in early nineteenth century America, especially in the writings of Washington Irving, David Anthony, adapting the work of Toby Ditz, argues a case for a 'gothic masculinity'. This gothic masculinity is constituted by "concepts of male selfhood, one centered less and less around an interior form of self-possession and "inner being", "and increasingly contingent upon a commodified and frequently "elusive" "form of reputation" (Anthony, 2005, 115). Catherine Spooner's gloss on this argument claims, in contrast, that alongside the fascination with surface, contemporary Gothic reveals a "pull towards interiority" (Spooner, 2006, 27). This clash or dynamic between surface and interior in the making of the self, I propose, takes recourse to the uncanny.

Let me first unravel the dynamic before moving on to the uncanny. I here build on an argument I have rehearsed elsewhere. I have argued that (i) Bruce Wayne's is the masculinity of the surface, an apparitional or "cool” masculinity, (ii) Batman, who lurks under Wayne's surface, is the tortured masculine interiority. It is the dynamic between this surface cool of millionaire playboy (Wayne) and the traumatized orphan-turned-crimefighter (Batman) that produces the masculinity -indeed self-identity- of Batman/Wayne (Nayar "Gothic Masculinity" ). This is of course unstable for, as Philip Orr has argued, "Wayne/Batman finds satisfaction only in a poststructuralist war against stable identities” (Orr, 1994, 169-170). (It is vaguely amusing to note that the gender the superheroes are emphasized in their very names -Batman, Superman, Spiderman, Aquaman, Wonder Woman, Cat Woman, Spider-girl.) This unstable self embodies the uncanny.

The uncanny, as Sigmund Freud famously demonstrated (1919), is about the human sense of "home and "not-home". It is about the human's perception of a place as akin to but not quite home. Hence, a certain hesitation, or epistemological uncertainty, leading to a "crisis of perception" marks the uncanny event/place (Weber, 1973, 1132). "I'm afraid that when I walk through those asylum gates ... When I walk into Arkham and the doors close behind me ... It'll be just like coming home", says Batman in Arkham Asylum. A place that is like home, and yet not quite. Batman has just gestured at the uncanny.

The uncanny in its Scottish etymological origins, Nicholas Royle points out, offers us "uncertainties at the origin concerning colonization and the foreign body, a mixing of what is at once old and long-familiar with is what is strangely "fresh" and new" (Royle, 2003, 12). Others seem to somehow converge on to us, for as Nicholas Royle puts it, the uncanny "may be construed as a foreign body within oneself, even the experience of oneself as a foreign body" (2, emphasis in original). This experience of the foreign as a part of ourselves, the figure of the 
foreigner as a part of our life, at least in a fleeting moment, is the uncanny. I propose that it is the uncanny incorporation of the foreign -the bat motif- that troubles and reinforces the selfhood of Bruce Wayne. His self contains the foreign, the other.

Batman comics refer to the bat as an "ancient" creature, and this is the creature that Wayne imports into his own life. In TDKR it is described as "gliding with ancient grace ... breath hot with the taste of fallen foes ... the stench of dead things". The ancient is what is inside Wayne/Batman as he others himself. The incorporation of the other species, beyond time and beyond borders, is what gives Wayne a self - Batman. In Batman: Gothic an ancient evil that never dies - he has made a pact with the devil - comes to haunt Gotham. Solomon Grundy, one of Batman's villains, is a zombie from the Victorian era, and cannot die either. In The Cult (1988), again, we have the resurrection of an ancient Native American shaman and his curse.

All this ties in with Nicholas Royle's reading of the uncanny as the assimilation or convergence of the foreign within us, and the uncertainties at/of the origins. I argue, extending this theme of uncertainty, that Batman's sense of self is based on a certain mystique: who is Batman? Batman's self that incorporates the foreign is neither Wayne nor the masked crimefighter, neither the confident playboy nor the terrifying-but-haunted knight. It is in the constant spectral play between these binary sets of identities that Batman is conjured. It is an apparitional self. He discovers this in Arkham Asylum: "Batman's not afraid of anything. It's me. I am afraid".

I would go so far as to suggest -as Alfred does, frequently- two layers to the apparitional self. This is the doubling, the spectral that constitutes the uncanny. First: that Wayne becomes the Batman mask. The mask is his self. And yet, the mask is also what others him to himself: Wayne, conscious of himself as a masked character, finds in his Batman-identity his radical and foreign Other from whom he cannot separate (One of the notable features of the Batman story arcs after 1980s is this intense self-reflexivity. Geoff Klock notes that such a self-consciousness is also visible in the $J L A$ stories where they make fun of each other's names, characteristics and attitudes. See also Klock, 2002, 127-8). Second: the mask not only distinguishes Batman from the other residents of Gotham, making him special as the caped-masked crusader, it also, ironically renders him ordinary: he is just another guy in a mask with no distinguishing features. The mask separates him from other ordinary people but also makes him completely without features. If meaning is literally a physiognomy, then Batman has no meaning because he lacks a physiognomy (except for that grimace). Thus the mask might be read as something that makes him completely the Other to the social order because it separates him from the rest, but also because he is the only one whose real face can never be known for us to relate to him face-toface. (The fact that superheroes in their more human identity have to be as invisible as possible suggests that ordinariness is itself a mask.) In All-Star Superman (February 2, 2006) Superman takes Lois Lane to his secret refuge and reveals to her that he is Clark Kent (he reveals this because, after his encounter with the excessive sun rays, he has supposedly begun to age). Lois Lane refuses to believe him. In the moments of introspection that follow this revelation, Lois Lane asks herself: "what if he is telling the truth ... what if there really was some part of him that was bumbling, oafish Clark Kent? ... I just don't know if l could live with that".

In Watchmen the mask Rorschach puts on serves a different purpose. Hearing of the murder of Kitty Genovese, Rorschach retrieves the fabric she had ordered at the dressmaker and forgotten. The fabric, which is two layers of latex filled with an inky fluid, he decides, can make a mask because after cutting it up it looks like the ink blots of the Rorschach test. "I went home, I took the remains of her unwanted dress, and made a face that I could bear to look at in the mirror", says Rorschach having designed his mask. The reference is of course to the masks supposedly civilized people wore when they watched Genovese being stabbed to death, but did nothing to stop. The mask here is of the radical Othering, and lack of empathy Rorschach sees 
in the city. When he puts on the mask, he is the ugly truth the city must face: he is the ugly face of the city itself.

Our demons, Miller's Wayne pronounces in TDKR, can be defeated. But Wayne does not defeat his demons, as we know: he is unable to fall asleep and has frequent nightmares of the death of his parents. The foreign is the distant past, the undying past, which is kept alive so that Batman can also live. In other words, what I am proposing is that the uncanny is the haunting that generates the identity of Batman. Without his nightmares, his anxieties, and his haunting, there is no sense of self.

The uncanny shifts and doublings between, the surface and the interior, the self and the foreign, the human and the animal, the 'normal' and the insane constitutes the apparitional selfhood of Batman. Batman experiences himself as foreign when his origins trouble him. Wayne also experiences himself as Batman. More importantly, the self partakes of the Other resulting in an uncanny point where it becomes difficult to distinguish between Self and Other, Wayne and Batman. The epistemological uncertainty of the uncanny here is the apparitional nature of both Wayne and Batman. I do not see, as should be obvious, Batman as Wayne's secret self or alter ego or even double, I see Batman as constitutive of what Wayne is, just as Wayne enbodies Batman.

I might also add that the revisionary narratives that introduce multiverses, parallel worlds and "hypertime" (Mark Waid's idea of interconnected parallel timelines that comprise all reality, first introduced in The Kingdom, 1998) and the famous Elseworlds (introduced by DC after the Crisis on Infinite Earths series of 1985-86) also suggest the uncanny because these other worlds and actions that occur there seem to double the good versus evil battle that occurs on earth. Karin Kukkonen suggests that these counterfactual scenarios (of superhero multiverses) are “mutually incompatible realities” (Kukkonen, 2010, 41). However, Kukkonen's argument does not account for two crucial aspects of texts like Crisis on Infinite Earths: (i) the superhero remains essentially the same and (ii) the events unfolding in alternate universes replicate, uncannily, the events on earth, and the superhero continues to battle evil. Thus, even when the location shifts to someplace other than home (earth) there is a doubling. The uncanny, one recalls, is about places similar to but not quite home. This is precisely what we see in multiverse comic stories.

\section{Altruistic Activism}

Greg Smith has noted that most secret heroes are corporate professionals in their alter egos: Clark Kent (Superman) is a journalist, Matt Murdock (Daredevil) is a lawyer, Tony Stark (Iron Man) is an industrialist, Peter Parker (Spider-man) is a journalist, Barry Allen (Flash) and Ray Palmer (Atom) are scientists, and Bruce Wayne (Batman) spends a considerable amount of time with his Wayne industries and their Boards. Smith notes that all of them are professionals who fit into their corporate institutional worlds, and none are small-business people or day laborers. Thus, Smith argues, the Organization Man is central to the superhero's secret identity. The first works within the social rules, norms and networks, the latter often bypasses these (Smith, 2009, $127,130)$. The official hero and the "outlaw" hero are combined into a single entity here.

Granted that the secret identity is enmeshed within the Organizational Man role Greg Smith has outlined, I propose that the superhero's self is based in large measure not on a sense of selfhood but on selflessness. Superman at one point even complains, in the midst of rescuing Lois Lane yet again: "I"ve a complaint! Rescuing you from scrapes takes up so much of my time, I"ve hardly time for anything else!" (Superman \# 397-414, April 22 - May 11 1940: 67). Here Superman is drawing attention to the fact that his ministry must serve as many people as possible, and not just one. And of course, all superheroes insist that they need not be thanked for what they do. Mark Waid presciently notes that "in helping others, Superman helps himself ... 
when he comes to the aid of other people, he is exercising his distinctive powers and fulfilling his own destiny". There is, writes Waid (2009, 3-10), "no contradiction here between self and society". The superhero represents the values of the society that produces him, claims Danny Fingeroth $(2004,17)$.

Batman story writer Jeph Loeb and Tom Morris have coined the term "altruistic activism" to describe the dedication of superheroes to doing good (Loeb, \& Tom Morris 14). Like Waid, they argue that what sets the superhero apart from the hero is realization that 'there is no his self-fulfillment without self-giving" (Loeb, \& Tom Morris, 2009, 15). It is because they keep the greater common good in mind that they are superheroes. In Justice League of America's Justice (\#1, 2005), the story claims, 'the so-called Justice League of America banded together because they were unwilling to allow us [humans] to bleed and suffer and learn to defend ourselves". This is the work ethic that characterizes the superhero mythos: nothing worth doing is easy, anything to save/help others is an ethical heroism. Superheroes, to phrase it differently, are driven by a heightened (some might say inflated) sense of responsibility (with the exception of Alan Moore and Dave Gibbons' Watchmen, in which the superheroes are driven by greed, power, careers - Sally Jupiter, known as the Silk Spectre, hopes to actually further her modeling career - and money, and not because their parents have been murdered).

At this point it must also be admitted that the superhero responsibility towards upholding justice and the law of the culture s/he lives in is embedded, as Jason Bainbridge argues, in a sense of the failure of existing systems of law enforcement and juridical responsibility. Superheroes represent, in this reading a pre-modern and sacralised sense of justice rather than a contemporary one. The superhero's ethos and ethics demands that he exist in opposition to rationality, that he supplement the failure of the law and be proactive rather than that he be just reactive. We see this tension between pre-modern and modern legalities in Miller's work (both in TDKR and Daredevil) where modern processes of the law (courts and the police) have to be circumvented in the "embodied justice" of Batman and Daredevil, but cannot be entirely abandoned. Supeheroes do function as Others to the legal processes, but somehow seem to be enmeshed in them as well. They patrol the borders of the legal and the legitimate: they are licit without being entirely legitimate. Thus, while they understand ideological state apparatuses like religion, education, politics they are not controlled by them; while they recognize and aid repressive state apparatuses like the law or the police, they are not dependent upon them. Indeed, superheroes demonstrate the limitations of the Repressive State Apparatuses (Hughes, 2006, 547).

While superheroes do not really share the same problems, anxieties or threats as the society they serve, their efforts at alleviating these very human problems are born out of the sense of altruistic activism. Following Waid following both Socrates and Aristotle, it could be argued that the excellent life led by the superheroes becomes the mainstay of their sense of self and happiness. It is the work ethic that determines and defines the superhero: his or her self consists of aiding humans in various difficult, threatening and impossible situations ranging from the ridiculous to the sublime.

\section{From Filiation to Affiliation}

The filial is a contested space in the superhero ethos. Most superheroes, as Richard Reynolds has argued, grow up with little familial structures backing them $(1992,16)$. There might be "mythical ontogeny", as Maurice Horn calls it, with notional families and lineages, but this is not, apparently, sustaining enough $(1976,80)$. Batman of course does possess a surrogate family: Nightwing, Robin, Oracle and others are often described as 'the Batman family. The Justice League, or Warren Ellis Authority could also be seen as an instance of the relational self, one situated within the surrogate family. 
Superheroes, in their individual capacities and as a community/group (the Justice League, the Eternals, etc.), take it upon themselves to serve humanity, perhaps because they are quasihuman. Superman and Batman have to earn the trust of the people (would you trust a person who has x-ray vision and possesses super-hearing in this age of phone-tapping?). Lacking a biological family in the human sense of the term, these superheroes embrace the family of mankind. It is also important to note that when they embrace humanity they also embrace humanity's ideals, values and systems, most notably the law. Superman began his life and career as a social reformer, taking on a wife-beater, a corrupt senator and rescuing a prisoner from a lynching mob. Indeed superheroes represent a fantasy where the hero deals with a deficiency in that society, mostly a deficiency in the law. Superman, wrote DC Comics President Paul Levitz, "was a fulfillment of a pent-up passion for the heroic solution" (57).

Lacking an immediate biological family, and badly socialized as a result, the superhero seeks validation, a horizontal connection. The orphan myth helps here. The superhero is one who is responsible for his choices. This constitutes, as Danny Fingeroth has pointed out, one of the great fantasies, "alone, with no help from anyone, you become tops in a variety of fields" (2004, $66)$.

The absence of filiation and the concomitant shaky self that results is compensated by a quest for this validation outside the "home". Superman is the perfect immigrant who has assimilated the values and norms of his adopted culture and thereby acquires an acceptance. Batman's relation with the best and the worst in Gotham is always tenuous, but is significant for him all the same. Superman's respect for the law is now somewhere between a truism and a matter of some ridicule. When for instance Superman as Kent wonders: "what shall I do? Personally attend to the remaining spies? ... No! II'll trick them into exposing themselves and let the law catch them red-handed", he reinforces the sanctity of the law and legal processes (Superman \#307-334, January 8-February 8, 1940: 23). The entire superhero mythos is based on this tenuous affiliation with the community the superhero chooses to serve rather than filial bonding or affection. Affiliation is the new family, in other words. The self is constructed in relation to affiliations that one chooses because it has no filiation which is "natural".

There is of course one exception to this: the Fantastic Four are a family, but also function as a great team for the greater common good, thus marking a conjunction of filiation with affiliation. Substitute and surrogate families have come into the picture with the Fantastic Four, the Justice League, and of course X-Men. The important thing is: the family is a team as well, fighting battles. They are united -and this makes it affiliation again- in their commitment to a greater cause. It is an affiliation based on the work they set out to do. This makes the Justice League, for example, or the Eternals or Avengers, an organization in which membership is granted based not only on your abilities but on your agenda and your commitment to a cause. Affiliation here is a management project for superheroes that bestows on them an identity, a sense of self. Even at a micro-level this is true. Take Batgirl: Year One (collected in paperback in 2003). When Batgirl (Barbara Gordon, James Gordon's niece and later adopted daughter, who, after being shoot by the Joker, becomes paralysed and becomes Oracle) seeks acceptance as a superhero capable of fighting evil, Batman is reluctant. Batman sets tests for her to see if she can be "one of us". She fails because she uses lethal force, something unacceptable in superhero ethics. Later, she passes a second time and asks Batman: "Do I pass? Will you finally acknowledge that I can do this?” Batman then takes her to the graves of the Waynes and takes off his mask, revealing his true identity and thereby admitting her into the circle. This is a moment of initiation, and Batgirl's admission is contingent not only upon her ability but her acceptance of the superhero code of conduct: that she will not use lethal force. The individual has to first accept the organization's aims, methods of working and principles: it is like any 
other employment.

As Others to the social order, these teams of superheroes, I suggest following Reynolds and Fingeroth, can be treated as groupings of, can ironically be treated as minorities (Reynolds 1992, 79; Fingeroth, 2004, 106). True, these are people with extra powers and enhanced abilities, but they remain, numerically at least, a minority. Hence the teams and clubs such as Justice League might be seen as an association for the interest of minorities. These associations are needed for them to define themselves. Take the case of the X-Men. Treated as outcasts -Othersby the social order that rejects them for being mutants, they band together for their own safety. The X-Men symbolize a persecuted minority -albeit with special qualities- that becomes the Other to the mainstream social order. The affiliation that bands them together is therefore more to do with an association of rejects than any kind of filial-familial relationship. What must also be kept in mind is that societies define themselves in relation to their Others. The superhero clubs, teams and communities function, therefore, as the minority against which the mainstream majority defines itself. In other words, the superhero clubs are essential to a social order's identity.

There is another angle to this filiation/affiliation business. Much of the crime-fighting superheroes do have a personal dimension. It proceeds from a personal sense of loss of family members, of grievance that leads Batman and Spider-man to fight crime. The loss of immediate family members to crime - thereby initiating the erosion of filiation as a space where the self can blossom - sets the superhero on the route to crime-fighting and thereby the acquisition of affiliation. Batman of course sees affiliation with the Joker ("What would you do without me?", he asks the Joker every chance he gets) as well as Two-Face: "I see a mere repetition, Harvey, a reflection", he says towards the end of TDKR, part I. The battle with the Joker appropriately takes place in the House of Mirrors, again suggesting that Batman and the Joker are mirror images. In Batman: Two-Faces, Batman and the Joker are one and the same. Batman thus finds himself within such affiliations rather than filiation. Batman, in other words, is less a self than a set of character traits which he then shares with others!

There is yet another dimension to this reflection theme. We know Batman as the haunted knight, a man who cannot ever let go of his traumatic past. Batman is affiliated to criminals, insane persons and others with whom he is in antagonistic relations also because he is extremely self-reflexive about his condition and sees parallels between himself and these so-called criminals. In Arkham Asylum Batman reflects just before he enters the asylum where distinguished criminals such as Two-Face and the Joker are incarcerated:

I'm afraid that the Joker may be right about me. Sometimes I question the rationality of my actions. And I'm afraid that when I walk through those asylum gates ... It'll be just like coming home.

Arkham Asylum is also the Batman text in which psychiatrist Ruth Adams proposes a new affiliation of Batman and the Joker. Adams suggests that it is not possible to define the Joker as insane. She goes on:

It's quite possible we may be looking at some kind of super-sanity here. A brilliant new modification of human perception, more suited to urban life at the end of the twentieth century ... Unlike you and I, the Joker seems to have no control over the sensory information he is receiving from the outside world... He can only cope with that chaotic barrage of input by going with the flow ... He has no real personality ... He creates himself each day...

Yet, as we know from TDKR, Year One and other texts, this is the person with whom Batman 
feels the greatest affinity (and something the Joker thrives on). The Joker constantly calls Batman's sanity into question: "You had a bad day and everything changed. Why else would you dress up like a flying rat?" (The Killing Joke). "You can't kill me without becoming like me. I can't kill you without losing the only human being who can keep up with me. Isn't that ironic?" asks the Joker (Batman \# 663). In Nolan's The Dark Knight Batman, when offered assistance by his clones, retorts: "I don't need help", and Dr Jonathan Crane (who will become Scarecrow) responds: "not my diagnosis". In Arkham Asylum the Joker tells Batman: "We want you in here with us in the madhouse where you belong".

There is one more instance of the affiliation of the insane. Amadeus Arkham and Wayne/ Batman have a lot in common. Arkham left Gotham and returned years later to bring order to the place by setting up the Arkham Asylum for the mentally ill. Both Arkham and Wayne are returned sons of Gotham. Both feel guilty about their parents: Arkham because he killed his mother and Wayne because he was responsible for their leaving the theatre and getting killed. And both see visions of a bat. Dr Cavendish forces Batman to read Arkham's journal in which he speaks of a bat and tells him: "I'm not fooled by that cheap disguise. I know what you are".

\section{Conclusion: Superheroes, Transhumanism and the Culture of Perfectibility}

Why would superheroes still be identified as human? I mean, why would "creatures" whose biological, psychological and social make-up situates them on the borders of the human be called "superman", "Wonder Woman", "X-Men" or "Cat Woman"? That they share characteristics of humans is obvious. What should be equally obvious is that they also exhibit characteristics, capabilities and propensities that cannot be identified as that of a "normal" human either. So to name them after "man" and "woman" is to ignore their ambiguous species -or racial-identity and draw them into the category of the human. Is it because their non-human aspects -strange powers, enhanced capabilities- become a source of anxiety that we have to humanize them? It is of course the consequence of a cultural anxiety that DC and Marvel ensure that superheroes serve the human race and not set about creating one of their own. By making the enhanced human a servitor, a trustee of the human race we not only ensure that the Other is incorporated into the larger project of humanity, but also that the threat of the superpowerful Other is alleviated. The Other is therefore not in an oppositional relationship with humans, but in a supportive role to the human projects of preserving life, wealth, property and the law.

I suggest that superheroes represent a, not necessarily a radically alien -Other- species or race. They rather represent, a culture of perfectibility of humans - more or less akin to the posthuman we see emerging in the 1990s (In the case of Superman, at least, there is no enhancement. In his "human" life he actually downgrades his qualities, whereas all other superheroes are humans who are enhanced - and this makes for an interesting paradox. I am grateful to Aniket Jaaware for pointing this out). The Other here is not alien but the embodiment of fantasy, of what we can ourselves evolve into. At this point I want to make a case for reading superheroes and their culture of perfectibility within the transhuman framework. I am in particular interested, in the anti-essentialist arguments made about species membership by transhumanist scholars such as Persson and Savulescu (2010). Transhumanists believe that technology can transcend the limitations of the human body and mind and therefore fetishize itself. But superheroes do possess technological prowess not necessarily of their own choice or making. Transhumanists believe in enhancement, some in a radical re-engineering of the human where the body can possess qualities no human has possessed before. Essentially enhancement takes a set of thus-far circumscribed human capabilities typical of the species (this is important) and expands/extends them (I am not debating the ethics of this enhancement vision. There is, of course, a key problem: somatic enhancement where I do something to my body so I can enjoy classical music better is radically different from gene line engineering where my future generations will also be "modified" for the 
same purpose. Germ line engineering in which I choose for all future generations is of an entirely different order).

Persson and Savulescu propose that an individual can belong to different species. Further, they argue that human enhancement might result in better moral sensitivity. Enhancement in this view might result in beings that are more human in the moral sense even if it means they cease to be human in the biological sense. Being members of a species does not entail a moral value, argue Persson and Savulescu. We see something of this conspecifics emerging in posthuman cultures with xenotransplantation, chimeras and genetic engineering. Computers, animals, humans are bioengineered together so that an individual can belong to different species at the same time. This also means that an individual can belong to one species at one time and to another at another time. Transhumanism believes that there ought to be a legal equality of humans and posthumans, and I have elsewhere pondered whether posthumans (biomedically, technologically enhanced humans called cyborgs) have human rights (Nayar, "Posthuman Rights"). Indeed many of the superhero themes and characteristics -as in much of sci-fi- are being borne out in scientific research and high-tech, from atomization to multiple universes to cloning. There was always something fantastic about superheroes, but "real" science has more or less caught up with fantasy now.

One of the features that mark human psychology, according to contemporary commentators, is the tendency to be social, and altruism. Altruism is more kin altruism, and rarely extends to perfect strangers (xenophobia is a general characteristic of humanity). But, argue Persson and Savulescu, suppose altruism or gratitude could be reinforced or enhanced. Suppose altruism could be enhanced to include xeno-altruism. Indeed one of the stated beliefs (aims?) of transhumanists is:

we might not be perfect, but we can make things better by promoting rational thinking, freedom, tolerance, democracy, and concern for our fellow human beings ... Just as we use rational means to improve the human condition and the external world, we can also use such means to improve ourselves, the human organisms.... (Humanity+).

Apparatuses like education are mechanisms of fine-tuning the supposedly "innate" qualities of goodness or morality in us. The family, religion, education and processes of socialization are directed at instilling certain values in the growing child. So, in effect, there really is no "natural" human. Transhumanism merely extends this social model of moral enhancement through technological processes.

We see something of this kind emerging in arguments about the "moral imagination", defined as the capacity to feel the "exigency of wrongs suffered by strangers at a distance", and in cosmopolitanism (Lacquer, 2001, 134; Appiah, 2006). Now, Persson and Savulescu suggest that instead of technological fixes for human problems, we could think of transhumanism as creating a new will among humans to solve these problems. If Superman can respond to a crisis in another corner of the world, if the Justice League can sort out interplanetary problems, then morally enhanced humans can, in principle, be made conscious of the sufferings of perfect strangers and to respond ethically to them. In other words, a cosmopolitan moral imagination is not an entirely absurd idea if we were to think of enhanced humans as conditioned technologically to respond to the Other. Studies show that pro-social behavior is imprinted in people through education. The entire premise of Authority is, Geoff Klock notes, to change the world and to carry humanity to where it thinks humanity should go instead of letting humanity reach wherever it wants under its own steam (as Superman suggests in $J L A \# 4$, Klock, 2002, 137). That is, the new politics of superheroes is to take charge of humanity. 
Given this ability to adopt norms, enhancing the ability to respond ethically is, again, in principle, possible. As Persson and Savulescu put it, "without moral enhancement, other techniques of biomedical enhancement seem likely to increase global injustice" because these would simply serve the cause of people in the developed world (2010, 667-8). "With great power comes great responsibility" would therefore mean that enhanced qualities imply enhanced altruism and sense of responsibility to take care of the distant other as well. Rather than kin altruism superpowers demand a xeno-altruism, resulting in a globalization of conscience. Indeed one commentator has described Batman as functioning as a "moral exemplar" to Robin (Nielsen).

Objections to transhumanist enhancement by thinkers like Francis Fukuyama involve the binary between "natural" humans and "synthetic" humans. Transhumanists do not see any human quality as immutable or sacrosanct. I propose that the range of abilities embodied in superheroes represents not simply a binary of "ordinary human" versus "advanced human" but a spectra of variation among humans. There is, already, considerable variation within the species (in fact contemporary theories in disability studies call us to see differently-abled people not as possessing a "lack" but as variants of the human model) - and this is all the more reason to think of ur-humans or posthumans, or superheroes, as one more variant of homo sapiens. It remains, undoubtedly, for humans to debate and act responsibly on the choice, degree and nature of enhancement that adds to this variety (There is within the transhumanist vision a black hole. There is little to suggest that they see posthumans as merely being a variation on/of the available human model. Instead there is a feeling one gets that they posit posthumans as desirable and reject those they see as "lacking" these enhancements. This might lead to a new form of genetic racism where the unenhanced life is not worth living. There is an urgent need, I think, to think of species improvement itself, where enhancements should be entitlements for everyone, like universal human rights).

Superheroes, I conclude, represent the minoritarian Other in a social order given to the tyranny of the majority in so-called democracy. Second we need to see superheroes as variants on the human theme. They represent the perfectible human, a fantasy that drives us to perform better.

\section{Acknowledgements}

An earlier draft of this essay was presented at a conference on 'Self and the Other', Department of Humanities and Social Sciences, Indian Institute of Technology, Mumbai, India February 2011.

\section{About the Author}

Pramod K. Nayar, PhD., teaches at the Department of English, University of Hyderabad, India. His recent publications include States of Sentiment: Exploring the Cultures of Emotion (2011), An Introduction to New Media and Cybercultures (2010) and Postcolonialism: A Guide for the Perplexed (2010), besides essays on superheroes, cultural studies and colonial discourse. 


\section{REFERENCES}

Superman The Dailies, vol. II: Strips 307-672, 1940-1941. New York, USA: DC Comics, 1999.

Anthony, D. (2005). Gone distracted: Sleepy hollow, gothic masculinity, and the panic of 1819. Early American Literature, 40 (1), 111-144.

Appiah, K. A. (2006). Cosmopolitanism: Ethics in a world of strangers. London, England: Penguin.

Bainbridge, J. (2007). This is the authority. This planet is under our protection: An exegesis of superheroes’ interrogations of the law. Law, Culture and the Humanities 3, 455-476.

Beatty, S., \& Dixon, C. (2003). Batgirl: Year One. New York, USA: DC Comics.

Chase, A. (2000). International law on film, Legal Studies 24. Retrieved from http://heinonline.org/HOL/ LandingPage?collection=journals\&handle=hein.journals/lstf24\&div=42\&id=\&page=, 20 Dec. 2010.

Fingeroth, D. (2004). Superman on the couch: What superheroes really tell us about ourselves and our society. New York, USA: Continuum.

Freud, S. (1971). The "Uncanny". In Collected Papers. Trans. Joan Riviere. Vol. 4. London, England: The Hogarth Press and the Institute of Psychoanalysis, 1919.

Horn, M. Ed. (1976). The World encyclopedia of comics. New York, USA: Chelsea House.

Hughes, J. A. (2006). Who watches the watchmen? Ideology and the "real world" superheroes. Journal of Popular Culture, 39(4), 546-557.

Humanity +. Transhumanist FAQ. Retrieved from http://humanityplus.org/learn/transhumanist-faq/. 22 December 2010.

Jenkins, H. (2009). “Just Men in tights”: Rewriting silver age comics in an era of multiplicity. Ed. Angela Ndalianis. The Contemporary comic book superhero, 16-43. London, England and New York, USA: Routledge.

Klock, G. (2002). How to Read superhero comic books and why. New York, USA: Continuum.

Kukkonen, K. (2010) Navigating infinite earths: Readers, mental models, and the multiverse of superhero comics. Storyworlds, 2, 39-58.

Laqueur, T. W. (2001). The Moral imagination and human rights. Ed. Amy Gutman, \& M. Ignatieff, Human Rights as Politics and as Idolatory, 127-140. Washington: Harvard University Press.

Loeb, J., \& Morris, T. (2009). Heroes and superheroes. Ed. Tom Morris, \& Matt Morris. Superheroes and philosophy: Truth, justice and the Socratic way, 11-20. Chicago, USA: Open Court.

Miller, F., \& Lee, J. (2008). All Star Batman \& Robin the Boy Wonder. 2005-08. New York, USA: DC Comics.

Miller, F., \& Varley, J. (2002). Batman: The Dark Knight Strikes Again. 2001-02. New York, USA: DC Comics.

Miller, F., with Janson, K., \& Varley, J. (2002). Batman: The Dark Knight Returns. 1986. New York, USA: DC Comics.

Miller, F., Mazzucchelli, D. with Lewis, R. (2005). Batman: Year One. 1986-7. New York, USA: DC Comics.

Moore, A., \& Gibbons, D. (1987). Watchmen. New York, USA: DC Comics.

Moore, A., \& Bolland, B. (1988). Batman: The Killing Joke. New York, USA: DC Comics.

Morrison, G., \& Janson, K. (1998). Batman: Gothic. New York, USA: DC Comics, 1998.

Morrison, G., \& McKean, D. (1989). Batman: Arkham Asylum: A Serious House on Serious Earth. New York, USA: DC Comics.

Morrison, G., Quitely, F., \& Grant, J. All-Star Superman. New York, USA: DC Comics, 2006.

Nayar, P. K. (2008). The Narrative tradition of posthuman rights. Ed. Andy Miah. Human Futures, 196206. Liverpool: FACT and Liverpool University Press, England.

Nayar, P. K. (2010). Gothic masculinity, filiation and affiliation: Frank Miller’s Batman, Families, 7 (2) and $8(1), 121-137$.

Nielsen, C. F. (2008). Leaving the shadow of the bat: Aristotle, Kant, and Dick Grayson on moral education. Ed. Mark D. White, \& Robert Arp, Batman and philosophy: The Dark knight of the soul, 
254-266. Malden, MA, USA: Wiley-Blackwell.

Orr, P. (1994). The Anoedipal mythos of batman and catwoman. Journal of Popular Culture, 27 (4), $169-182$. Persson, I., \& J. Savulescu. (2010). Moral transhumanism. Journal of Medicine and Philosophy, 35, 656-669. Reynolds, R. (1992). Superheroes: A Modern mythology. London, England: BT Batsford.

Robinson, L.S. (2004). Wonder Women: Feminism and superheroes. London, England and New York, USA: Routledge.

Royle, N. (2003). The Uncanny. Manchester, England: Manchester University Press.

Smith, G. (2009). The Superhero as labor: The corporate secret identity. Ed. Angela Ndalianis. The Contemporary Comic Book Superhero, 126-143. London, England and New York, USA: Routledge.

Spooner, C. (2006). Contemporary Gothic. London: Reaktion.

Stabile, C. (2009). 'Sweetheart, this ain't gender studies': Sexism and superheroes. Communication and Critical/Cultural Studies, 6 (1), 86-92.

Waid, M. (2009). The Real truth about superman: And the rest of us, too. Ed. T. Morris, \& M. Morris. Superheroes and philosophy: Truth, justice and the Socratic way, 3-10. Chicago, USA: Open Court.

Weber, S. (1973). The sideshow, or: Remarks on a canny moment. MLN 88, 1102-1133. 